\title{
Association of Coronavirus Disease 2019 and Stroke: A Rising Concern
}

\author{
Murali Krishnan Kolikonda ${ }^{a}$ Kranthi Kumar Jandrasupallib Steven Lippmann ${ }^{c}$

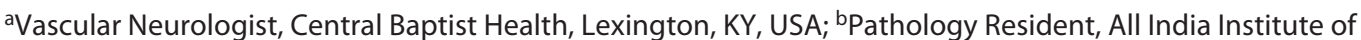 \\ Medical Sciences, Rishikesh, Uttarakhand, India; ' Emeritus Professor in Psychiatry, University of Louisville School of \\ Medicine, Louisville, KY, USA
}

\section{Keywords}

Acute stroke $\cdot$ COVID-19 Neuroinvasive mechanism

\begin{abstract}
The severe acute respiratory syndrome coronavirus 2 (SARSCov-2) causes the coronavirus disease 2019 (COVID-19). It quickly became pandemic, and so did a new concern about COVID-19 infections increasing the risk for cerebrovascular diseases. There is an association between COVID-19 illness in people and acute stroke. Several chemical, mechanical, and/ or inflammatory central nervous system pathologies are proposed to explain how this viral infection might induce acute cerebrovascular disease. Timely available evaluation and/or intervention is imperative for patients with concerns about acute cerebrovascular issues.

○ 2020 S. Karger AG, Basel
\end{abstract}

\section{Introduction}

The severe acute respiratory syndrome coronavirus 2 (SARS-CoV-2) causes the coronavirus 2019 (COVID-19) disease, which quickly became a pandemic [1]. COVID-19 induces significant mortality and is currently without a specific treatment or vaccine. Beyond knowing that bacteria and viruses can be risk factors for cerebrovascular ischemia, the impact of this novel coronavirus on emergency medical issues like acute ischemic stroke remains to be clarified [2]. Stroke accounts for 1 of every 20 fatalities in the USA, is a leading cause of long-term disability, and is the second most common cause of death [3]. During this COVID-19 pandemic period, there were reports of decreased stroke presentation patients and emergency stroke diagnoses [4]. Where are all these people? Is there a true decrease in stroke incidence? Is our COVID-19-focused health care system and media currently providing less attention to other serious conditions and emergencies like acute stroke?

\section{Association: COVID-19 and Stroke}

Medical facilities are encountering unusually long delays before patients seek attention for acute emergencies [5]. Recently, there has been 39\% decrease in the timeliness of people receiving acute stroke evaluations based on a review of neuroimaging databases from the RAPID software platform (iSchemaView) [6]. Newly diagnosed stroke rates have declined by $38 \%$ during this COVID period, while the proportion of new large vessel occlusions doubled in a retrospective single-center study [4]. An association between COVID-19 and large vessel occlusion was reported in 5 young patients [7]. Among 221 Chinese patients hospitalized for COVID-19, 11 evidenced an acute ischemic stroke [8]. The median time from SARS- karger@karger.com

www.karger.com/ned

Karger"

(c) 2020 S. Karger AG, Base 


\section{Mechanism of central nervous system invasion by SARS-CoV-2}

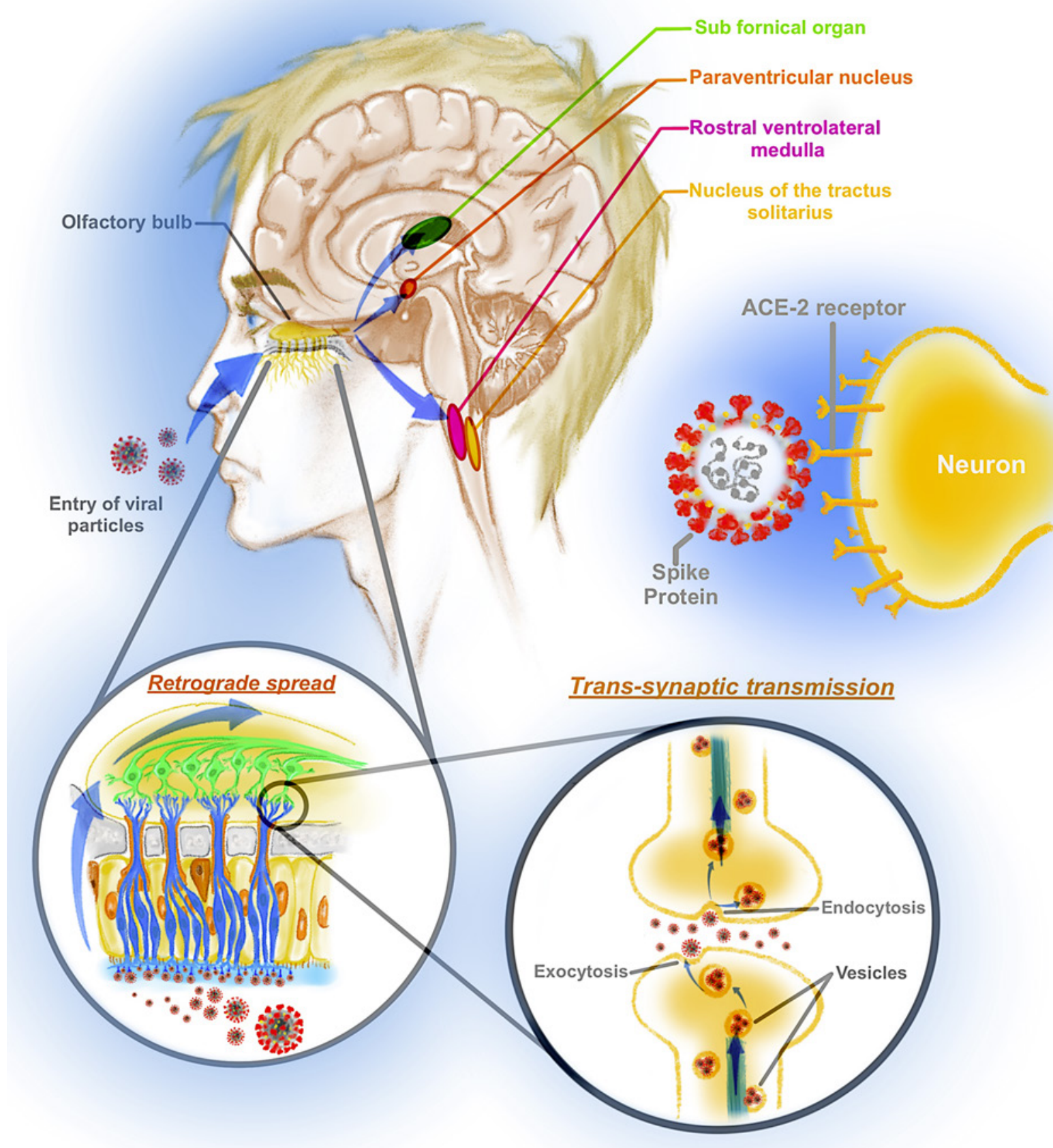

Fig. 1. Mechanism of central nervous system invasion by SARS-CoV-2. 


\section{Mechanism of SARS-CoV-2 causing stroke}

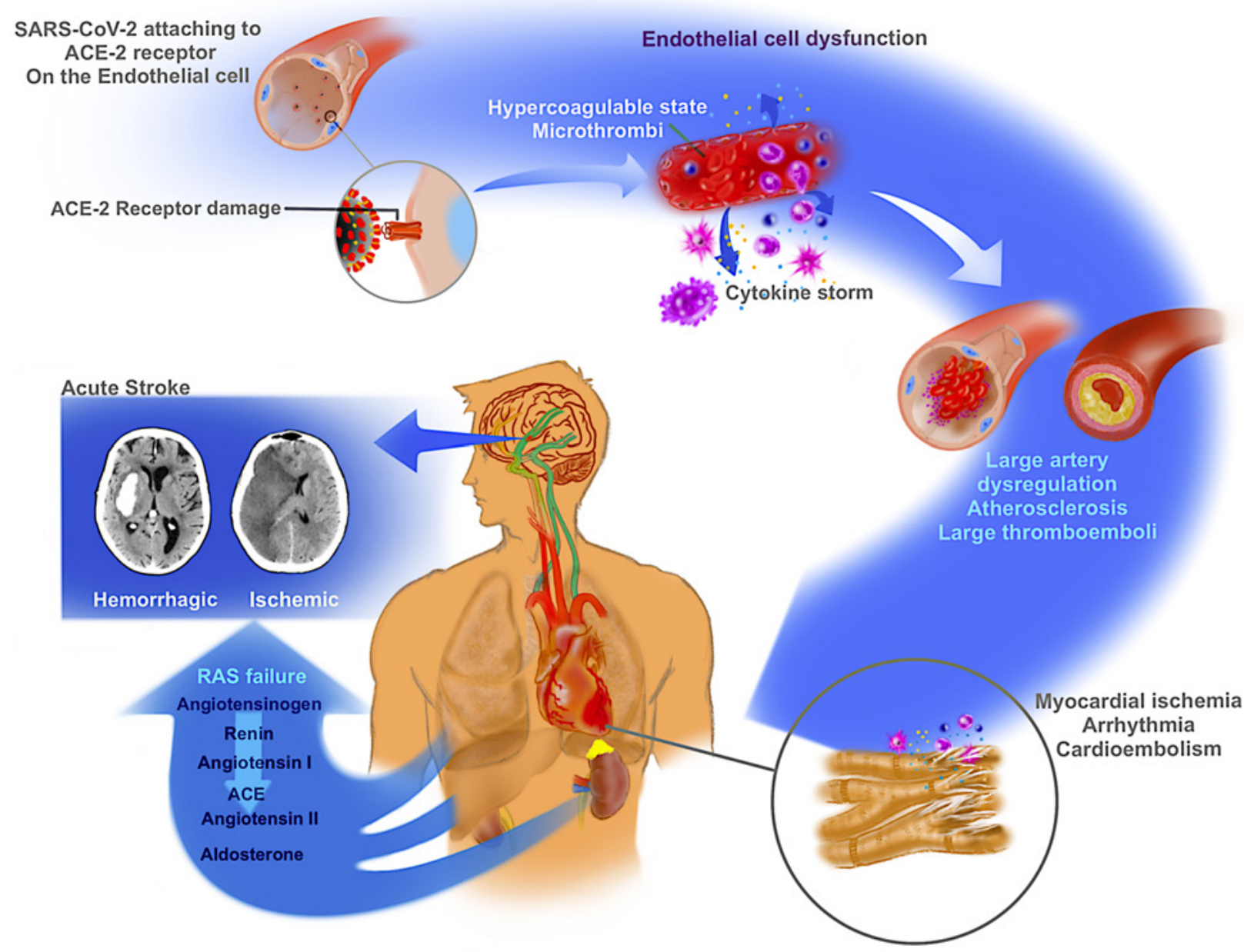

Fig. 2. Mechanism of SARS-CoV-2 causing acute stroke.

CoV-2 infection to detection of cerebrovascular disease was about 12 days. A retrospective hospital study documented 4 people with SARS-CoV-2 confirmed diagnoses and imaging-proven acute stroke [9]. These observations raise concern about a potential link of COVID-19 to acute stroke.

\section{Proposed Neuroinvasive Mechanism of SARS-CoV-2}

Although the exact mechanism of SARS-CoV-2 causing cerebrovascular pathology is unclear, there might be a neuroinvasive potential that increases the incidence of stroke, thromboses, and related neuropsychiatric conditions [10-12]. A viral invasion into the tissues is described via angiotensin-converting enzyme 2 and evident in the subfornical organ, paraventricular nucleus, rostral ventrolateral medulla, and nucleus of the tractus solitarius [13]. A possible nasal invasion to the olfactory bulb through the trans-synaptic route is the proposed mechanism of central nervous system penetration [14-16]. The viral invasion of mechano- and chemoreceptors in the medulla can lead to respiratory failure [17] (Fig. 1). Coronavirus induces a systemic inflammatory cytokine cascade, which can cause severe coagulopathies, leading to thrombocytopenia; elevation of C-reactive protein, $\mathrm{d}$-di- 
mer, fibrin, or fibrinogen degradation products; and fibrinogen [18-20]. The alternative renin-angiotensin pathway system in the brain contributes to effects that are antihypertensive, angiogenic, antithrombotic, antiatherosclerotic, neuroprotective, and antioxidant. These might be disrupted due to coronavirus infection, potentiating the increased incidence of cerebrovascular events [21] (Fig. 2). A comorbid COVID-19 infection with an ischemic stroke worsens the prognoses [22].

\section{Patient and Hospital Factors}

Following COVID-19 infection control measures, an increasing number of people defer requests for medical care. Self-quarantined, they sometimes delay seeking help to avoid contagion in emergency departments. Such postponements have occurred more often during this pandemic. These COVID-19 control concerns are yielding the unintended consequence of people with a possible stroke, delaying their emergent presentation and resulting in more complications [23, 24]. This, too, can overload hospital capacities. Inevitable delays from hospital response systems may follow whenever staff is consumed more than usual with precautionary measures to prevent SARS-CoV-2 exposures. Compounding these hospital and patient factors would lead delay treatment. This delay in stroke care results in prolonged hospitalizations, more disabilities, and additional acquired infections, including COVID-19. Such circumstances could further overwhelm health care systems, yielding suboptimal resource allocation.

\section{Conclusion}

Timely stroke intervention and corona testing of appropriate patients is crucial. While coronavirus precautions are being relaxed, acknowledging COVID-19 associations to cerebrovascular disease helps plan health care services and should improve clinical outcomes. Education about SARS-CoV-2 and what to do about COVID-19 infections is beneficial. Although an association between COVID-19 and stroke has gained recent attention, current evidence does not establish causality. Although there have been published reports on decline in stroke presentations during the COVID-19 pandemic, there could be a surge of acute cerebrovascular pathologies with growing emergence of association between COVID-19 and stroke [25]. Maintaining the availability of timely evaluation and/or intervention for patients with acute cerebrovascular diseases is imperative.

\section{Conflicts of Interest Statement}

No potential conflicts of interests for all authors.

\section{Funding Sources}

The authors did not receive any funding.

\section{References}

1 Ghebreyesus TA. WHO director-general's opening remarks at the media briefing on COVID-19: 11 March 2020. : https://www. who.int/dg/speeches/detail/who-directorgeneral-s-opening-remarks-at-the-mediabriefing-on-covid-19---11-march-2020.

2 Grau AJ, Buggle F, Becher H, Zimmermann E, Spiel M, Fent T, et al. Recent bacterial and viral infection is a risk factor for cerebrovascular ischemia: clinical and biochemical studies. Neurology. 1998;50(1):196-203.

3 Benjamin EJ, Blaha MJ, Chiuve SE, Cushman M, Das SR, Deo R, et al. Heart disease and stroke statistics - 2017 update: American heart association report. Circulation. 2017; 135:e229-445.

4 Siegler JE, Heslin ME, Thau L, Smith A, Jovin TG. Falling stroke rates during COVID-19 pandemic at a comprehensive stroke center. J Stroke Cerebrovasc Dis. 2020;29(8):104953.
5 Tam CF, Cheung KS, Lam S, Wong A, Yung A, Sze M, et al. Impact of coronavirus disease 2019 (COVID-19) outbreak on ST-segmentelevation myocardial infarction care in Hong Kong, China. Circ Cardiovasc Qual Outcomes. 2020 Mar 17.

6 Kansagra AP, Goyal MS, Hamilton S, Albers GW. Collateral effect of covid-19 on stroke evaluation in the United States. N Engl J Med. 2020;383(4):400-1.

7 Oxley TJ, Mocco J, Majidi S, Kellner CP, Shoirah H, Singh IP, et al. Large-vessel stroke as a presenting feature of Covid-19 in the young. N Engl J Med. 2020;382(20):e60.

8 Li Y, Li M, Wang M, Zhou Y, Chang J, Xian $\mathrm{Y}$, et al. Acute cerebrovascular disease following COVID-19: a single center, retrospective, observational study (3/3/2020). https://ssrn. com/abstract $=3550025$. http://dx.doi.org/ $10.2139 /$ ssrn.3550025.
9 Avula A, Nalleballe K, Narula N, Sapozhnikov S, Dandu V, Toom S, et al. COVID-19 presenting as stroke. Brain Behav Immun. 2020; S0889-1591(20):30685-1.

$10 \mathrm{Wu} \mathrm{Y,} \mathrm{Xu} \mathrm{X,} \mathrm{Chen} \mathrm{Z.} \mathrm{Nervous} \mathrm{system} \mathrm{in-}$ volvement after infection with COVID-19 and other coronaviruses. Brain Behav Immun.

11 Klok FA, Kruip MJHA, van der Meer NJM, Arbous MS, Gommers DAMPJ, Kant KM, et al. Incidence of thrombotic complications in critically ill ICU patients with COVID-19. Thromb Res. 2020;S0049-3848(20):30120-1.

12 Tan CW, Low JGH, Wong WH, Chua YY, Goh SL, Ng HJ. Critically ill COVID-19 infected patients exhibit increased clot waveform analysis parameters consistent with hypercoagulability. Am J Hematol. 2020. 
13 Netland J, Meyerholz DK, Moore S, Cassell $\mathrm{M}$, Perlman S. Severe acute respiratory syndrome coronavirus infection causes neuronal death in the absence of encephalitis in mice transgenic for human ACE2. J Virol. 2008; 82(15):7264-75.

$14 \mathrm{Xia} \mathrm{H,} \mathrm{Lazartigues} \mathrm{E.} \mathrm{Angiotensin-converting}$ enzyme 2: central regulator for cardiovascular function. Curr Hypertens Rep. 2010;12(3): $170-5$.

15 Li YC, Bai WZ, Hashikawa T. The neuroinvasive potential of SARS-CoV2 may play a role in the respiratory failure of COVID-19 patients. J Med Virol. 2020.

16 Ding Y, He L, Zhang Q, Huang Z, Che X, Hou $\mathrm{J}$, et al . Organ distribution of severe acute respiratory syndrome (SARS) associated coronavirus (SARS-CoV) in SARS patients: implications for pathogenesis and virus transmission pathways. J Pathol. 2004;203(2):622-30.
17 Li YC, Bai WZ, Hirano N, Hayashida T, Taniguchi T, Sugita Y, et al. Neurotropic virus tracing suggests a membranous-coating-mediated mechanism for transsynaptic communication. J Comp Neurol. 2013;521(1):20312.

18 Levi M, Toh CH, Thachil J, Watson HG. Guidelines for the diagnosis and management of disseminated intravascular coagulation. British committee for standards in haematology. Br J Haematol. 2009;145(1):24-33.

19 Henry BM, Vikse J. Clinical characteristics of Covid-19 in China. N Engl J Med. 2020; 382(19):1860-61.

20 Han H, Yang L, Liu R, Liu F, Wu KL, Li J, et al. Prominent changes in blood coagulation of patients with SARS-CoV-2 infection. Clin Chem Lab Med. 2020;58(7):1116-20.
21 Divani AA, Andalib S, Di Napoli M, Lattanzi S, Hussain MS, Biller J, et al . Coronavirus disease 2019 and stroke: clinical manifestations and pathophysiological insights. J Stroke Cerebrovasc Dis. 2020;29(8):104941.

22 Siniscalchi A, Gallelli L. Could COVID-19 represent a negative prognostic factor in patients with stroke? Infect Control Hosp Epidemiol. 2020;1:1.

23 Teo KC, Leung WCY, Wong YK, Liu RKC, Chan AHY, Choi OMY, et al. Delays in stroke onset to hospital arrival time during COVID-19. Stroke. 2020;51(7):2228-31.

24 Montaner J, Barragán-Prieto A, Pérez-Sánchez S, Escudero-Martínez I, Moniche F, Sánchez-Miura JA, et al. Break in the stroke chain of survival due to COVID-19. Stroke. 2020.

25 Uchino K, Kolikonda MK, Brown D. Decline in stroke presentations during COVID-19 surge. Stroke. 2020;51. 